\title{
The Effect of Liquid Organic Fertilizers in The Refugia Block on Visiting Insects in The Apple Orchard and Community Knowledges in its Conservation Efforts
}

\author{
Mohamad Nasirudin ${ }^{1}$, Amin Setyo Leksono², Nia Kurniawan² \\ ${ }^{1}$ Masters Program in Environmental and Development Resources Management, \\ Postgraduate of Brawijaya University, Malang \\ ${ }^{2}$ Biology Program, Faculty of Mathematics and Natural Sciences, Brawijaya University, Malang
}

\begin{abstract}
This study aims to determine community structure and composition of liquid organic fertilizer (POC) against visiting insects in block Refuge and to determine the public perception of the block Refuge and insect's conservation. Analysis of insects data are obtained from the important of index value, diversity (index's Shannon Wienner). Insect abundance spring that treatment total 298 individuals and control 168 individuals. Insect abundance spring that treatment total 262 individuals and control 116 individuals. Insect diversity during flowering season given treatment was 2,11 andcontrol 1,49. Diversity during fruiting season was similar, given treatment it was 1,87 and control 1,42. Abundance of insect on both seasons with treatments and control had a significance of $P=0,004$. Similarities between insects on flowering season treatments between fruiting season treatments between organic fertilizers of different seasons 0,94 and control 0,80. Analysis on abiotic factors correlated with insect abundance with R-square value of $15 \%$. Local perception towards refugia blocks was found to be low (46\%) and medium (48\%). Local perception towards convservation was found to be low (34\%) and medium (63\%). Local perception is affected by knowledge and non responsive actions towards insect conservation.
\end{abstract}

Key words: Insect, Liquid Organic Fertilizer, Refugia

\section{INTRODUTION}

Apple cultivation takes about 4-5 years, depending on the factors that affect one of them is the climate [1]. The heyday of apple crops in Indonesia occurrs in the 1970s until the 1990s. The more advanced tourism in the Batu city spur people to take advantage of apples to be processed into typical food in batu such as crackers. the decreasing of abundance and diversity of insects may influence in quality and quantity of apple production in apple orchard

The decrease in the diversity of insects is caused by increased use of chemicals [2]. Improper use of chemicals in pest control can provide side effects such as target pests being resistant to pesticides, non-target animal deaths, and secondary pest explosions, soil environment contamination due to accumulation of chemical remains unabsorbed by plants, water and air will have an impact on human health dan non-target organism [3].

Author's Correspondence Address: Mohamad Nasirudin

Email : nasirudinmohamad@unwaha.ac.id

Address : Pengelolaan Sumberdaya Lingkungan Program Pascasarjana Universitas Brawijaya
Apples in Batu City were affected by volcanic ash from the eruption of Mount Kelud that caused many dead insects [4]. Volcanic ash contains several chemical compounds, one of which is sulfur (S). The $\mathrm{S}$ element on volcanic ash causes a decrease in the number of insects.

Special care is needed to preserve the insects in apples. The effort to maximize the performance of natural enemies present on farmland is by creating insect habitats to increase insect populations. Provision of habitat for insects is by utilizing wild plants that potentially becomes refugia apple orchards. Plants used as refugia are Ageratum conyzoides, Ageratum houstonianum, and Bidens pilosa $[5,6,7]$.

The sustainability of insects by the utilization of organic material in apple plants. Wild plants in the apple orchard acts as a weed, pest stop and plant diseases. Farmers generally clean up the wild plants in the apple orchard. Farmers do not understand the role of wild plants as a shelter for natural enemies.

This study aims to determine the structure of the community, the composition and the influence of liquid organic fertilizer (LOF) against insects visiting the refugia block and to know the public Knowledge of refugia blocks and the conservation of insects. 


\section{RESEARCH METHODS}

This research uses observational and visual control method with quantitative research type. Data retrieval using this method applies non destructive techniques. Insect observations were done visually in the refugia blocks in the plot between the apple trees. Observation of insects in the refugia block in the flower and fruit phase. The parameters observed were all types of insects visiting the refugia block, and then observed the abundance and diversity of insects. The measurement of abiotic factors is temperature, humidity and light intensity. Public Knowledge of the role of insects, the role of liquid organic fertilizer, wild plants as refugia and understanding about conservation.

The research location is in Tulungrejo Village, Bumiaji, Sub-District of Batu City, with an area of 1 ha. The study was conducted during the spring of $13,17,21,25$, January 29 , and the fruit season on 17, 21, 25, 29 March, $2^{\text {nd }}$ of April, and from December 2014 to May 2015. Insect observations per hour periodicallyat 07:00 to $08: 00 \mathrm{pm}$, at $09: 00$ to $10: 00 \mathrm{pm}$, at $12: 00$ to $13: 00 \mathrm{pm}$, and at $15: 00$ to $16: 00 \mathrm{pm}$.

An insect abundance analysis was used to find out the Important Value Index (INP), Diversity Index of Shannon-Wiener ( $\left.\mathrm{H}^{\prime}\right)$ and BrayCurtis Similarity Index (IBC). Analysis of abiotic environmental factors (temperature, humidity, and light intensity) is attributed to the abundance of insects.

\section{RESULTS AND DISCUSSION}

\section{Community Structure andComposition of Insects Visiting the Refugia Block}

The results of observation of insects visiting refugia block showed that during springtime and fruit season in the field with POC and Control treatment obtained 844 individual insects, consisting of 7 Orders and 15 families (Table 1).

\section{1a. Springtime}

The result of abundance of insect in refugia block with $\mathrm{POC}$ treatment obtained a higher insect result $(14,9)$ than Control $(8,4)$. Abundance of insects is higher with treatment given POC than Control, because the fertilizers and pesticides are applied in Control is relatively much use of inorganic materials, resulting in target and non target insect were dead. The result is that the abundance and diversity of the insects was decreasead [8].

The result of analysis of treatment data given by LOF was found to be relative abundance (KR) (Figure 1) with INP method obtained by Tabanidae family (34,5\%), Megachylidae family $(15,4 \%)$, Chrysomelidae family (11,7\%), Formicidae family $10 \%$ ), and Cercopidae family (4.7\%). On the control of KR values from Tabanidae family (54.1\%), Megachylidae family (18.4\%), Chrysomelidae family (10.7\%), Alydidae family (4.7\%), and Asilidae family (3.6\%).

INP insects at treatment with highest POC were Tabanidae family $(43,8)$, Megachylidae family (24,6), Chrysomelidae family (21), Forminicae family $(15,6)$, and Cercopidae family (14).In control of insects having the highest INP of Tabanidae family $(70,2)$, Megachylidae family $(34,5)$, Chrysomelidae family $(26,8)$, Alydidae family $(14,4)$, and Asilidae family (13,2) (Fig. 2).

Table1. Insect Population in Refugia Block During Flower and Fruit Season at Tulungrejovillage of Batu City, 2014

\begin{tabular}{|c|c|c|c|c|c|c|c|c|}
\hline \multirow{2}{*}{ No } & \multirow{2}{*}{ Ordo } & \multirow{2}{*}{ Families } & \multirow{2}{*}{ Roles } & \multicolumn{2}{|c|}{ Springtime } & \multicolumn{2}{|c|}{ Fruiting Season } & \multirow{2}{*}{ Total } \\
\hline & & & & POC & Control & POC & Control & \\
\hline \multirow[t]{2}{*}{1} & Lepidoptera & Lycaenidae & Polinator & 2 & 2 & 10 & - & 14 \\
\hline & & Tortricidae & Polinator & 9 & - & - & - & 9 \\
\hline \multirow[t]{5}{*}{2} & Diptera & Tephritidae & Polinator & 12 & 2 & 10 & - & 24 \\
\hline & & Tabanidae & Polinator & 103 & 91 & 106 & 66 & 366 \\
\hline & & Dolichopodidae & Predator & 2 & 3 & - & - & 5 \\
\hline & & Asilidae & Predator & 9 & 6 & - & - & 15 \\
\hline & & Sepsidae & Detrivor & 1 & - & - & - & 1 \\
\hline \multirow[t]{2}{*}{3} & Homoptera & Jassidae & Herbivor & 11 & 2 & 8 & 5 & 26 \\
\hline & & Cercopidae & Herbivor & 14 & 1 & 11 & 2 & 28 \\
\hline \multirow[t]{2}{*}{4} & Hymenoptera & Megachylidae & Polinator & 46 & 31 & 20 & 7 & 104 \\
\hline & & Formicidae & Predator & 30 & 4 & 34 & 5 & 73 \\
\hline \multirow[t]{2}{*}{5} & Coleoptera & Coccinellidae & Predator & 5 & - & 9 & 7 & 21 \\
\hline & & Chrysomelidae & Herbivor & 35 & 18 & 44 & 21 & 118 \\
\hline 6 & Hemiptera & Alydidae & Herbivor & 13 & 8 & 3 & 2 & 26 \\
\hline \multirow[t]{2}{*}{7} & Odonata & Macromiidae & Predator & 6 & - & 7 & 1 & 14 \\
\hline & & Total & & 298 & 168 & 262 & 116 & 844 \\
\hline
\end{tabular}




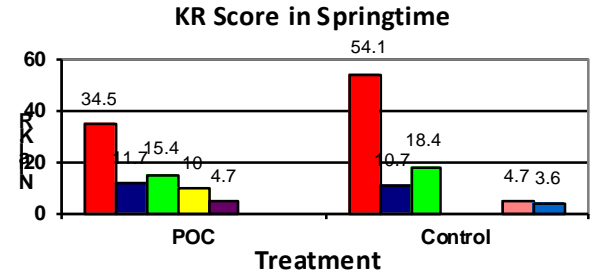

Figure 1. The relative abundance value of the springtime insects

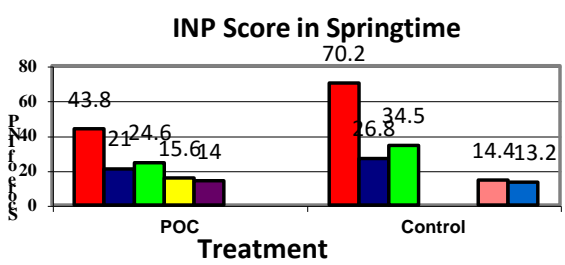

Figure 2. INP of Insect in springtime in Refugia Block.

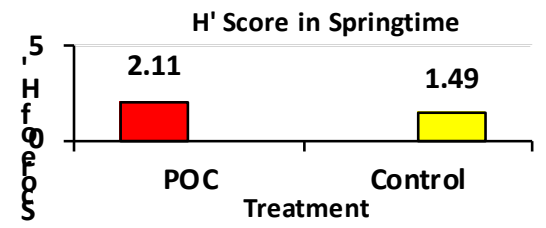

Figure 3. Value of diversity index ( $\left.\mathrm{H}^{\prime}\right)$ of flower season

The result of data analysis with Shannon Wiener method on (Figure 3) obtained the value of diversity index ( $\mathrm{H}^{\prime}$ ') of insects during the flower season with treatment given POC $(2,11)$, and Control $(1,49)$. Higher $H$ 'values in $P O C$ treatment than Controls because ingredients used to make POCs are made from organic ingredients, while ingredients in Control by apple farmer used chemical fertilizers and pesticides that can kill target and non target insects. It is suggesting that, the higher the diversity of a community type, the higher the likelihood of interaction between species [9]. Ecosystems with high diversity values generally have longer and more complex food chains, making it more likely for interactions such as parasitism, competition, commensalism and mutualism.

\section{1b. Fruit Season}

Result of abundance of insect in refugia block by INP method (Figure 4) obtained POC treatment that succeeded in obtaining insect higher that is $(13,1)$ than Control $(8,4)$. The results of analysis of treatment data given LOF hence known relative abundance (KR) from Tabanidae family (40,4\%), Chrysomelidae family $(16,7 \%)$, Formicidae family $(12,9 \%)$,
Megachylidae family (7,6\%), and Cercopidae family (4.2\%).

The value of INP insect (Fig. 5) in treatment with highest LOF was Tabanidae family $(51,3)$, Chrysomelidae family $(27,6)$, Formicidae family $(21,6)$, Megachylidae family $(18,5)$, and Cercopidae family 13). The highest INP values were in Tabanidae Family Control (56.8), Chrysomelidae family (37.3), Megachylidae family (25.2), Coccinellidae family $(21,4)$, and Formicidae family (12). Results of data analysis of diversity index ( $\left.\mathrm{H}^{\prime}\right)$ insect treated with POC (1.87), and Control (1.42).

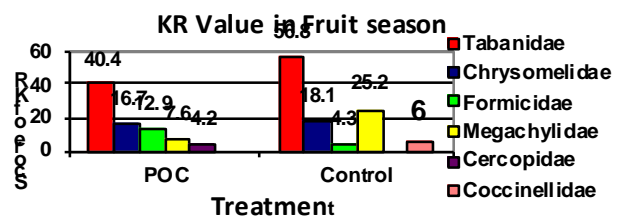

Figure 4. Relative abundance values $(\mathrm{Kr})$ Insects in fruit season

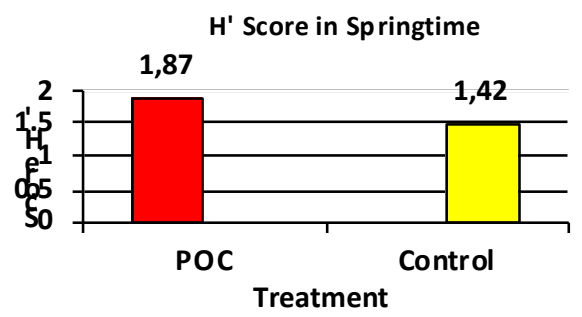

Figure 5. INP The springtime insects in the refugia block

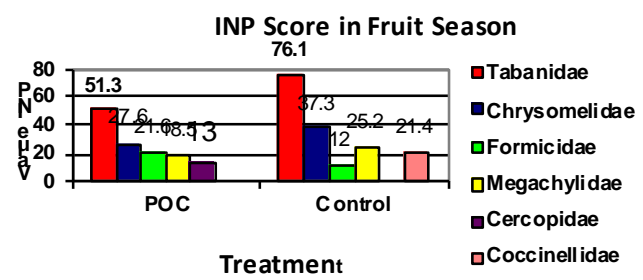

Figure 6. The value of diversity index ( $\mathrm{H}$ ') fruit season.

Diversity ( $\mathrm{H}^{\prime}$ ) (Figure 6) was obtained by the value of diversity index $\left(\mathrm{H}^{\prime}\right)$ of insect during fruit season with treatment given POC $(1,87)$, and Control (1.42). The population growth of an organism is due to the availability and resources available in each habitat [10].

Based on the results of statistical analysis, the abundance of both the flower season and the fruits was known to the insects visiting the refugia block with the yield variables on the abundance and treatment given LOF and Control significance value $P=0.004(P<0.05)$, so the abundance and treatment had a real effect 
against insects visiting the refugia block between treatments given LOF and Control.

The results of statistical analysis of the results of abundance of insects per day based on observation of the family were aimed to determine the average how different families of insects obtained on each day of observation. Based on the homogeneous subtests, it was obtained the highest significance of the Tabanidae family is 1.00 . So the family of Tabanidae abundance per day at most, so that the most significant different to other insects. Analysis of the results of the treatment in each season obtained significance $P=0.33, P=0.06$ and $P=0.11$ ( $P>0.05$ ), so the results did not significantly affect the treatment at each season.

The absence of a significant effect on seasonal yields due to the low value of insect abundance in treatments was given $\mathrm{POC}$ and Control, due to the utilization of chemicals that continue to increase over time by farmers on control treatment. The result of the analysis of abundance to the observation time clock was obtained the significance of $P=1.0$ (at 15.0016.00 WIB) and $P=0,10(07.00-08.00,12.00$ $13.00,09.00-10.00$ WIB) so $(P>0,05)$, so the abundance has no significant effect on clock time.

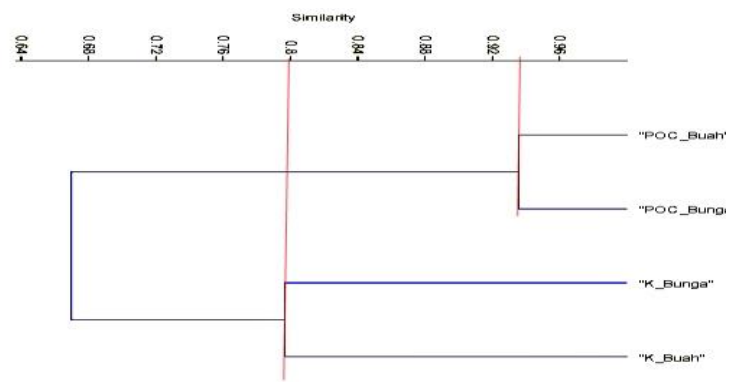

Figure 7. Dendogram of the same composition of insects visiting the refugia block between treatments given $\mathrm{POC}$ and Control

\section{Composition Similarity of Visiting Insect in Refugia Block}

Based on the calculation (Bray Curtis Index) IBC with the classification method (Figure 7) it is known that the comparison of insects visiting the refugia block during the flower season with $\mathrm{POC}$ treated and control obtained IBC value of 0.73 , which means the level of similarity of insects by $73 \%$.In the fruit season with POC and Control treated the IBC value of 0.60 , which means that there is $60 \%$ similarity of insects. In springtime and fruit season with POC treated then obtained an IBC value of 0.94 , which means there is an insect similarity of $94 \%$. In the springtime and fruits season Control obtained the IBC value is 0.80 , meaning there are similarities of insects by $80 \%$. IBC calculations obtained by a dendogram of the same composition of insects visiting the refugia block between treatments were given $\mathrm{POC}$ and Control.

\section{Daily variation of Visiting Insects in Refugia Block}

3a. POC Treatment in springtime

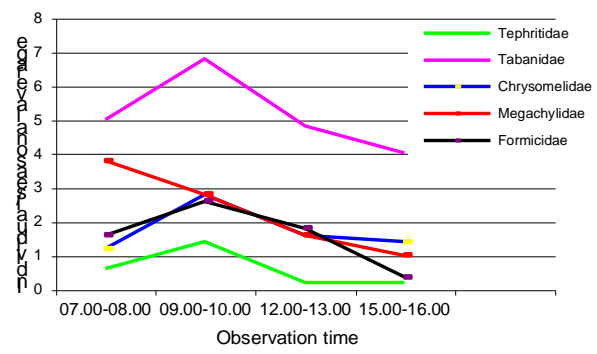

Figure 8. The mean of daily abundance of insects visiting the refugia block during the springtime with POC treatment

\section{3b. Springtime Control}

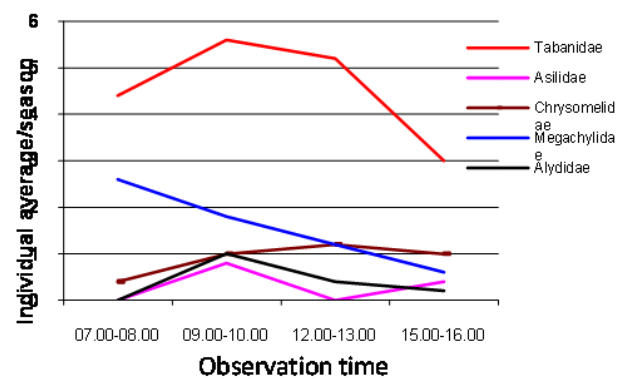

Figure 9. Average daily abundance of insects visiting the refugia block during Control season

\section{3c. Treatment control in fruit season}

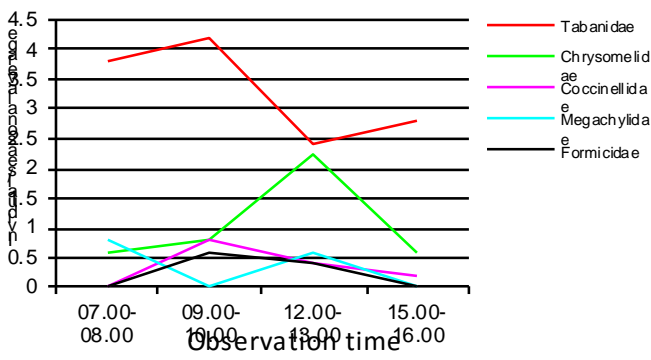

Figure 10.The mean of the abundance of visiting insect in refugia block in control fruit season 


\section{3d. Treatment of POC Fruit season}

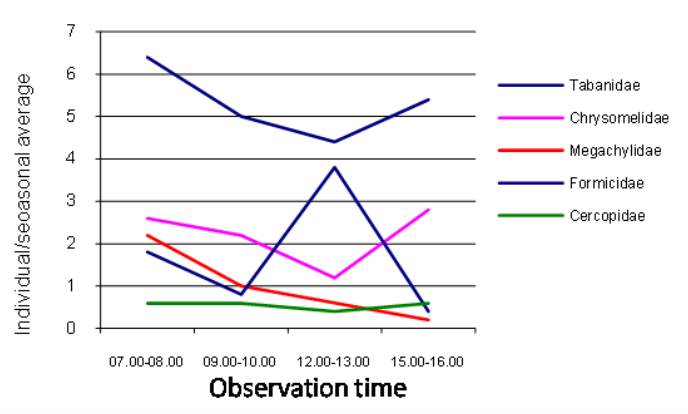

Figure 11. The mean of daily visiting insect abundance in refugia block in fruit season by the POC treatment

\section{Comparison of Pre-Pest and Post-Volcanic} Insect Impact Structures in the Refugia Block

The structure of the insect community in the refugia block of apple orchard in Bumiaji, Batu City, in pre-impact of volcanic ash was once researched by Abidin in 2013 [9]. The abundance of insects found was 234 individuals consisting of 14 families, the most dominant of the Apidae family has the role as a polinator. At the time of the fruit season abundance was found 169 individuals that consisted of 13 families. Most dominating insects from the family Formicidae has the role as a predator. The overall diversity of insect families found in the pre-impact of volcanic ash is 16 families. Formicidae were reported as a dominant family in a variety of habitats $\mathrm{e} . \mathrm{g}$ in olive cultivation fields, konjack, grassland, farmland [11,12]. Formicidae occupies several functional roles in the ecosystem including predator and scavenger [13].

The structure of the insect community found after the impact of volcanic ash in the refugia block of during the flowering season was 466 individuals consisting of 15 families, most dominating the Tabanidae family as a pollinator. In fruiting season, the abundance was 378 individuals consisting of 11 families, which is dominated Tabanidae family which has the role as a pollinator. The overall diversity of insect species found after the impact of volcanic ash is 15 families. Tabanidae is one of the refugia attracting families in paddy field study. The abundance occurred in the afternoon [14].
Table 2. Comparison of Pre-Pest and Post-Volcanic Insect Impact Structures in Refugia Block

\begin{tabular}{|c|c|c|c|}
\hline No. & $\begin{array}{l}\text { Insect in pre } \\
\text { eruption }\end{array}$ & No. & $\begin{array}{c}\text { Insects after } \\
\text { eruption }\end{array}$ \\
\hline 1. & Megachylidae* & 1. & Megachylidae* \\
\hline 2. & Formicidae* & 2. & Formicidae* \\
\hline 3. & Coccinellidae* & 3. & Coccinellidae* \\
\hline 4. & Chrysomelidae* & 4. & Chrysomelidae* \\
\hline 5. & $\begin{array}{l}\text { Allagapta } \\
\text { oblique }\end{array}$ & 5. & Alydidae \\
\hline 6. & Apis melifera & 6. & Asilidae \\
\hline 7. & Borbo & 7. & Cercopidae \\
\hline 8. & $\begin{array}{l}\text { Catopsilia } \\
\text { pyranthe }\end{array}$ & 8. & Dolichopodidae \\
\hline 9. & Copestylum & 9. & Jassidae \\
\hline 10. & Delias & 10. & Lycaenidae \\
\hline 11. & $\begin{array}{l}\text { Hypolimnas } \\
\text { bolina }\end{array}$ & 11. & Macromiidae \\
\hline 12. & Noctuidae & 12. & Sepsidae \\
\hline 13. & Sphecidae & 13. & Tabanidae \\
\hline 14. & Syrphidae & 14. & Tephritidae \\
\hline 15. & Tachinidae & 15. & Tortricidae \\
\hline 16. & Vespula & & \\
\hline
\end{tabular}

\section{The Effect of Abiotic Environmental Factorson} visiting insects in the Refugia Block

The existence of insects in a habitat is influenced by abiotic factor. In this study, the observed abiotic factors are air temperature, humidity, and light intensity. Of these three abiotic factors affect the abundance and diversity of insects residing in a habitat.

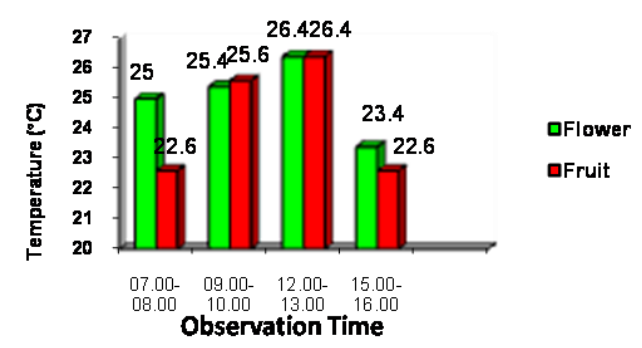

Figure 12. The mean comparison of air temperature in apple orchard in springtime and fruit season.

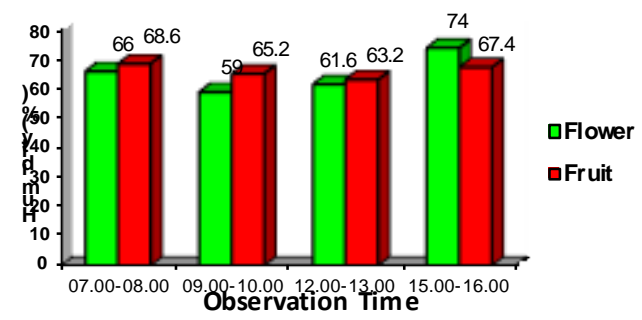

Figure 13. The mean of comparison air humidity (\%) in apple orchard in springtime and fruit season. 


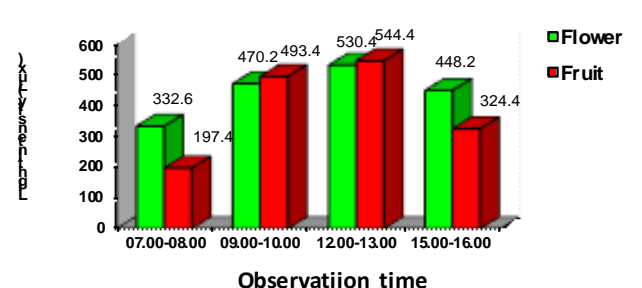

Figure 14. Comparison of mean light intensity (Lux) in apple orchards between flower and fruit season

The abotic analytical factor was done by using correlation test. The result of correlation test was coefficient score by 0,151 or $15 \%$ from insect's abundance that was affected by the temperature, humidity and light intensity, the remaining $85 \%$ was affected by some factors such as the abundance and the available food diversity. The correlation equation with coefficient test known abiotik factor of temperature in season has a positive correlation to abundance of insect that obtained a value of 0,06 and light intensity value 0.001 . The humidity factor is negatively correlated, thus affecting the abundance of insects in the refugia block. The result of abiotic factors between the springtime and the fruits did not show any significant difference, so the abundance present in both seasons was not so different.

Generally, the effective temperature range for insects is a minimum temperature of $15^{\circ} \mathrm{C}$, optimum temperature $25^{\circ} \mathrm{C}$, and a maximum temperature of $45^{\circ} \mathrm{C}$. At the optimum temperature the ability of insects to produce large offspring and mortality rates [9].

\section{AnAnalysis of Soil Contents}

\section{6a. Pre Treatment}

The results of analysis of soil content before the land were given POC and Control, as follows:

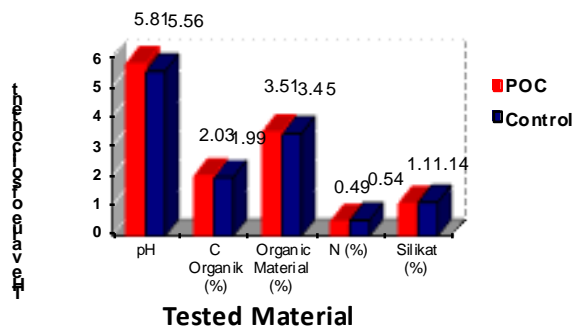

Figure 15. The soil content before given POC andControl

\section{6b. After Treatment}

Soil analysis after treatment

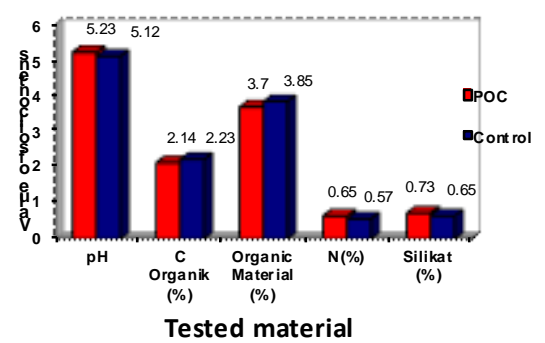

Figure16. The soil content after given POC andControl

7. The CommunityKnowledges about the Influence of POC Implementation in Block Refugia against Visiting Insect

Public Knowledge was analyzed by closed question method from 35 respondents (apple farmers). The average level of education of respondents in Tulungrejo Village is junior and senior high school.

\section{7a. The community Knowledge about insects}

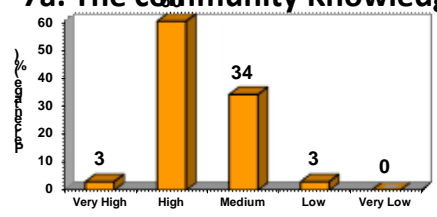

Figure 17. The community Knowledge about insects

The high knowledge of apple farming communities about insects is influenced by farming and counseling from farmer community or agricultural department. Farmers' attitude towards insects is they do not expect insects to be in the apple orchard. Farmers always try to eradicate the insects in the garden by using synthetic pesticides.

\section{7b. Community Knowledge about Refugia}

Community Perception about Refugia

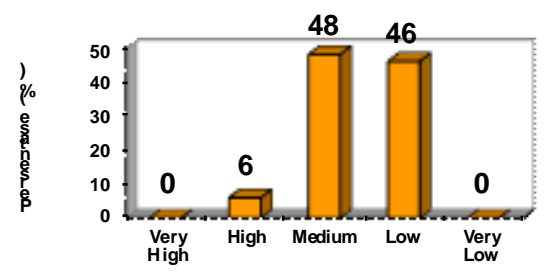

Figure18. Community Knowledge about Refugia

Many farmers frequently clean the yard of apples orchard from the wild plants (weeds) that found in the garden. The farmers assume weeds 
in the garden will affect pest insects for plants. Wild plants that exist around the garden, in addition to its function as refugia for insects, can also be used to prevent soil erosion by rain.

\section{7c. Community Knowledge about the Changes of Pre Abstract Abundance and Post- Eruption of KeludMount}

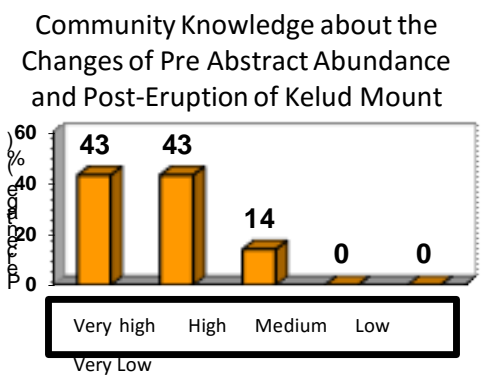

Figure19. Community Knowledge about the Changes of PreAbstract Abundance and Post-Eruption of Kelud Mount

Based on the interview result on respondents, the average respondent knows the change of abundance of insects and the impact caused by Kelud eruption. Response shown by respondents, they less agreed to maintain the sustainability of insects in the apple orchard. The presence of insects tends not to be expected in the garden. In addition to being assisted by wind, insects are a major component for apple crops to assist the pollination process.

\section{7d. Community Knowledge about Changing Soil Quality and Pre-Fruit and Post-Eruption of Kelud Mount}

\section{The changing od insect abundabce in Pre} and after Kelud Mount Eruption

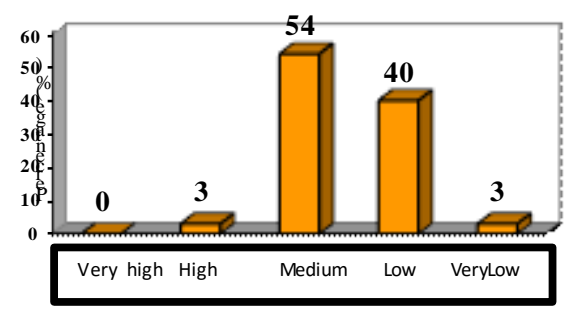

Figure 20. Community Knowledge about Changing Soil Quality and Pre-Fruit and Post-Eruption of Kelud Mount

Respondents were aware of changes the decrease of quality and quantity of apples after the impact of volcanic ash. Volcanic ash caused the soil become sour. Many respondents gave a lime on their land by hoping the increase of $\mathrm{pH}$ level in the soil to be normal. Apple plants can grow well and fertile in level of $\mathrm{pH}$ 6-7 [14].

\section{7e. Community Knowledge aboutConservation}

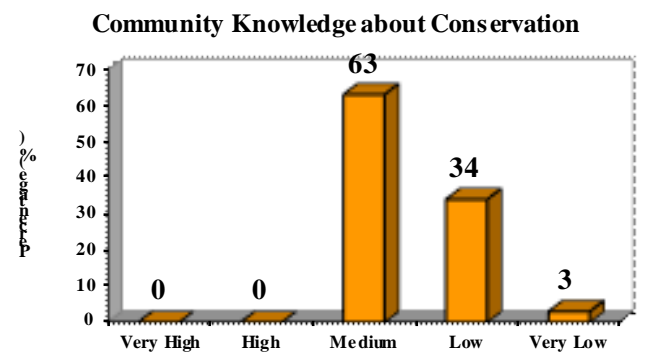

Figure 21. Community Knowledge about Conservation

The knowledge of the respondents on conservation is low and medium. This is due to the attitude of respondents who do not agree with maintaining the sustainability of insects by allowing plants that has a role as refugia in apple plantations, and they switch the use of inorganic fertilizers into organic fertilizers whereas some of them understand the conservation.

By maintaining conservation will be able to minimize the expenditure of maintenance costs and can improve soil conditions. What the respondent needs to do is to change the inorganic agriculture to semi organic farm with the concept of IPM. Semi-organic farming is the link from inorganic agriculture to organic farming.

\section{CONCLUSION}

The diversity of insects based on the family found in the apple orchard refugia block in the flower season with POC treatment was obtained by 7 orders from 15 families, the highest CR and INP values of the Tabanidae family, Megachylidae, Chrysomelidae, Formicidae, and Cercopidae, with diversity levels of (2.11).

On Control obtained 6 ordo from 11 families. The highest values of $\mathrm{Kr}$ and INP were from the families of Tabanidae, Megachylidae, Chrysomelidae, Alydidae, and Asilidae, with a diversity level of (1.49). In the fruit season with treatment given by $\mathrm{POC}$, it was obtained 7 ordo from 11 families. The highest values of $\mathrm{Kr}$ and INP were from the families of Tabanidae, Chrysomelidae,Formicidae, Megachylidae, and Cercopidae, with a diversity level of (1.87). On Control obtained 6 ordo from 9 families. The highest values of $\mathrm{Kr}$ and INP were from the families of Tabanidae, Chrysomelidae, 
Megachylidae, Coccinellidae, and Formicidae, with a diversity level of (1.42).

Public perceptions on refugia blocks are categorized in the low to moderate category, with low categories by $46 \%$ and moderate by $48 \%$. Public perceptions on conservation are considered low to moderate, with low categories by $34 \%$ and moderate by $63 \%$.

\section{ACKNOWLEDGMENTS}

The authors would like to say thank you very much to the Director of Postgraduate Universitas Brawijaya. We thank to Mr Arief that guided us and fully supported in this research.

\section{REFERENCES}

[1] Soelarso, R.B. 1997. Budidaya Apel. Yogyakarta. Kanisius.

[2] Pora, M.S. Leksono, A.S. Afandhi, A. 2016. Types of Insects in Organic and SemiOrganic Citrus Plantation. Indonesian Journal of Environment and Sustainable Development 7:2, pp

[3] Leksono, A. S. (2017). The effect of organic farming systems on species diversity. AIP Conference Proceedings 1908, 030001.

[4] Nadiah, A. 2014. Dampak Abu Vulkanik Hasil Erupsi Gunung Kelud Terhadap Komoditas Perkebunan Di Kabupaten Blitar. Balai Besar Perbenihan dan Proteksi Tanaman Perkebunan Surabaya.

[5] Apituley, F.L., A.S.Leksono, B. Yanuwiadi. 2012. Kajian komposisi serangga polinator tanaman apel (Malus sylvestris) di Desa Poncokusumo Kabupaten Malang. El-Hayah. 2:85-96.

[6] Purwantiningsih, B., Leksono, A. S. \& Yanuwiadi. B. 2012. Kajian Komposisi Serangga Polinator pada Tumbuhan Penutup Tanah di Poncokusumo, Malang. Berkala Penelitian Hayati 17 (2): 165-172.

[7] Muhibah, T. I. Leksono, A. S. 2015. Attraction of Arthropods in Refugia Blocks (Ageratum conyzoides L., Capsicum frustecens L., and Tagetes erecta L.) with the application of Liquid Organic Fertilizer in Apple Crops in Poncokusumo. Jurnal Biotropika 3; 3 pp 123-127.

[8] Kevan, P.G. and T.P. Phillips. 2001. The Economic Impact OfPolinator Declines: An Approach to Assesing the Consequence. Conservation Ecology 5(1):8.

[9] [Leksono, A.S. 2007. Ekologi : Pendekatan Deskriptif dan Kualitatif. Malang. Bayumedia Publishing.
[10] Krebs, C.J. 2001. Ecology: The Experimental Analysis of Distribution and Abundance. 5th ed. Benjamin Cummings. Menlo Park, California.

[11] Azmi, S. L., Leksono A. S., Yanuwiadi, B., and Arisoesilaningsih, E. 2014. Diversitas Arthropoda Herbivor Pengunjung Padi Merah di Sawah Organik di Desa Sengguruh, Kepanjen. Jurnal Pembangunan dan Alam Lestari, 5 (1): 57-64.

[12] Widyastuti R. 2002. Soil fauna in rainfed paddy field ecosystems: their role in organic matter decomposition and nitrogen mineralization. Ecology and Development Series Band 3. Cuvillier Verlag, Göttingen.

[13] The Refugia Attract Arthropods in a Paddy Field in Malang, East Java, Indonesia Amin Setyo Leksono, Jati Batoro, Anisa Zairina RJLS, Vol 5, No 2 (2018), pp. 89-97

[14] Mustakim, A., A.S. Leksono, Z. Kusuma. 2014. Pengaruh blok refugia terhadap pola kunjungan serangga polinator di perkebunan apel poncokusumo, Malang. Natural B 2:248-253. 